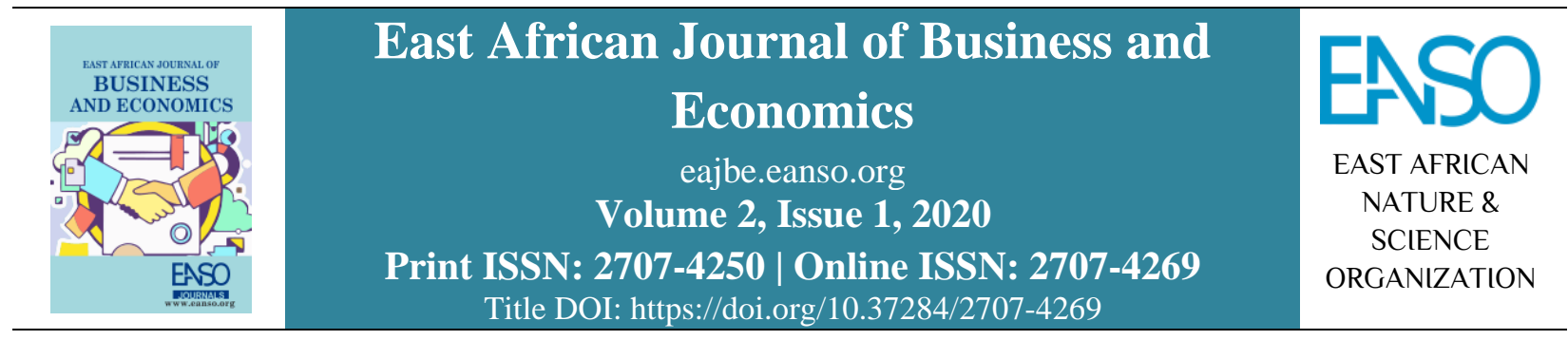

Original Article

\title{
Influence of Lending Procedures on Credit Accessibility amongst Small and Micro Enterprises in Kenya: A Case of Meru Town
}

\author{
Avignon Mbiti Ngumbi ${ }^{1 *}$, Dr. Gabriel Waweru ${ }^{1}$ \& Dr. Lyria Rita ${ }^{1}$ \\ ${ }^{1}$ Meru University of Science and Technology, P. O. Box $972-60200$, Meru, Kenya. \\ * ORCID: https://orcid.org/0000-0001-9695-958X; Correspondence email: avignonngumbi4@gmail.com.
}

Article DOI: https://doi.org/10.37284/eajbe.2.1.253

\section{Date Published: ABSTRACT}

12 December 2020 In Kenya, SMEs are businesses employing between 1-50 people and maybe either in formal or informal sectors and may also be in farm or non-farm

Keywords: categories. Due to the sector importance, Kenya has enacted several laws in support of SMEs. The SMEs require a concerted effort from both private and

Credit Accessibility, public since the sector draws stakeholders from both. To enhance their Small and Micro

Enterprises, sustainability in the economy, the SMEs require serious empirical research in order to elicit the constraints with the goal of developing proactive remedial SMEs, Lending Procedures. frameworks so that their existence may be promoted. Amongst the numerous challenges that constrain the working of SMEs is inadequate financing, thus the derivative of the overall goal of this study. The study location was Meru town. The descriptive research design was used. As per the Meru county government records, 160 SMEs are permitted and have been in operation for not less than 3 years. From every SME, one respondent was used. Census was adopted as the study design informed by the small population and the ease of reaching the respondents. A questionnaire was used to collect data through a drop-pick method which was done in three days' time. Data analysis was through descriptive methods. Data analysis was assisted by SPSS version 22 by subjection to regression analysis to establish the existence of relatedness between the dependent and independent variables. Presentation of results was done through tables. Analysis done indicated the existence of crucial relations between the process of loaning. Regression analysis results indicated the loaning procedure had a significant effect on credit accessibility among SMEs in Meru Town. It was recommended further study to be conducted to find out the other determinants of credit accessibility amongst SMEs in Meru town.

\section{APA CITATION}

Ngumbi, A. M., Waweru, G., \& Rita, L. (2020). Influence of Lending Procedures on Credit Accessibility amongst Small and Micro Enterprises in Kenya: A Case of Meru Town. East African Journal of Business and Economics, 2(1), 84-94. https://doi.org/10.37284/eajbe.2.1.253 


\section{CHICAGO CITATION}

Ngumbi, Avignon Mbiti, Gabriel Waweru, and Lyria Rita. 2020. "Influence of Lending Procedures on Credit Accessibility amongst Small and Micro Enterprises in Kenya: A Case of Meru Town". East African Journal of Business and Economics 2 (1), 84-94. https://doi.org/10.37284/eajbe.2.1.253.

\section{HARVARD CITATION}

Ngumbi, A. M., Waweru, G. and Rita, L. (2020) "Influence of Lending Procedures on Credit Accessibility amongst Small and Micro Enterprises in Kenya: A Case of Meru Town”, East African Journal of Business and Economics, 2(1), pp. 84-94. doi: 10.37284/eajbe.2.1.253.

\section{IEEE CITATION}

A. M. Ngumbi, G. Waweru, and L. Rita, "Influence of Lending Procedures on Credit Accessibility amongst Small and Micro Enterprises in Kenya: A Case of Meru Town”, EAJBE, vol. 2, no. 1, pp. 84-94, Dec. 2020.

\section{MLA CITATION}

Ngumbi, Avignon Mbiti, Gabriel Waweru, and Lyria Rita. "Influence of Lending Procedures on Credit Accessibility amongst Small and Micro Enterprises in Kenya: A Case of Meru Town”. East African Journal of Business and Economics, Vol. 2, no. 1, Dec. 2020, pp. 84-94, doi:10.37284/eajbe.2.1.253

\section{INTRODUCTION}

Some enterprises such as the Small and Micro Enterprises (SMEs) are commended for the vast revolution of many economies globally (World Bank, 2015). SMEs are recently dominating the global business arena, covering about $95 \%$ of world enterprises (Edinburgh Group, 2013). In addition to that, these SMEs account for the majority of employment opportunities in the private sector contributing about $60 \%$ of the employment.

The SMEs are an economic pillar due to the immense employment and income they provide to the larger population portion compared to the other sectors. Due to this, their potential has drawn the government attention since they assist in poverty alleviation through employment creation and thus, come up with policies in their legislative role. In relation to a survey done in 2016 , jobs created in SME increased by a rate of 1.5 million people in three years, that is, between 2012 and 2015 accounting for up to $75.3 \%$ of all the people as per the interview conducted in 2016. The SMEs comprise 18.4 per cent of the national GDP (CBS, 2016). The SME zone should not only major in providing goods and services but also be a key driver of enhancing competitive and innovative ideas, promoting a development culture necessary for the growth of both the private industry and industrialisation.

\section{Statement of the Problem}

Credit access is considered a vital factor in SMEs development and improving their income levels, employment increment and poverty alleviation. It enables them to overcome liquidity constraints and enable investment. Most SMEs rely on owners 'personal resources, loans from friends and relatives to fund their investments. Generally, though banks are relatively liquid, they are reluctant to lend to SMEs (Muguchu, 2013) across the globe including Meru town Since there are many firms that are giving credit-related programs to SME's, research done by Central Bureau of Statistics (2018) points to only $4 \%$ access to the credit by SME's. A study by Sultana (2012) estimating that only 2 per cent of SME's account holders access business development support services from these financial institutions.

This shows SME's in all areas in Kenya, including Meru town, are faced with financial challenges including inadequate capital and very constrained credit accessibility as they try to enhance quality and value in financial management practices. Nationwide research was done by the CBK, 2015 on accessing capital noted that SME's credit's access declined from $13.5 \%$ up to $9.1 \%$ within three years even though there is an increase in demand for funds in the SME sector (CBK (2015). This decline indicates a challenge in getting credit from 
credit institutions, including SMEs in Meru town. These findings indicate a dip in credit accessibility, a clear indicator of a problem with credit accessibility amongst SME's and thus, it is vital to look in details the determinants of credit accessibility amongst SME's in Kenya, looking at the case of Meru town. This study aimed at filling this gap.

There are various studies undertaken to understand the determinants of credit accessibility amongst SMEs which are varied from region to region with the results not giving conclusive answers on how various determinants influence the SMEs credit accessibility, which suggests there is existent financing gap in SMEs and as such the study is meant to establish the determinants for accessing facilities such as credit by SMEs in Kenya, with a case of Meru town in focus. This study broadly aimed at studying how loaning procedures as a determinant of the accessibility to credit in Kenya influence credit access among SMEs in Meru Town. It was hypothesised that:

$\boldsymbol{H}_{o 1}$ : There is no significant relationship between lending procedures and credit accessibility amongst SMEs in Meru town.

\section{LITERATURE REVIEW}

Research by Mungai and Miller (2015) found that lending firms relate reduced administrative costs to the size of the loan given. Njiru (2014) did research on how to get funding services in Kiambu and realized that the general size of loans was below $\$ 180$ marked with restrictions that it should run for twelve months. Due to the nature and value that relates to SME entities involved and the resultant small volume of the loans applied for, and the fact that lending rates are too high even to the excess of 30 percent per annum which is aimed at reducing the risks levels associated with liberated lending, the SMEs tend to shy away from credit application from the lenders. On the same note, IMF report assessment (Bergthaler et al., 2015) showed that this is an unpleasant approach of funding SME projects. The research recommends SMEs not to borrow and explore other modes of raising capital instead of borrowing at such high costs, moreover, the SMEs prefer to borrow the small amounts to cover for their immediate needs since they find difficulty in controlling huge finances in their business endeavours which easily leads to their strain and probably business failure. Loaning is mostly pegged on SMEs saving by MFIs and their credit repayment history. Another consideration is the recovery convenience, flexible payments and the previous experience with the borrowers. These are managed through encouraging financing of the SMEs working capital through short term loans of smaller values. Lending firms declare the fault as the SME management and their governance, unrealistic operation financial reports, insufficient and unsustainable resources for common loaning procedures, and collateral expectations as the central hindrance factors to lending to SMEs (OECD, 2015).

Borrowing is essentially a short-term goal due to inefficient credit culture, credit enforcement challenges, and lack of formalized documentation and collateral (Öztürk \& Mrkaic, 2014). Moreover, even though SMEs perceive the high-interest rates as a hindrance, they do not seem to have problem with getting high amounts at high-interest rates if the repayment instalments favour their ability to pay. In the event of huge instalments due to nonsupporting cash flows or unfavourable product features, the cost of finance is seen to be huge (OECD, 2015). This is partly because low instalments values even if they represent high money cost may be perceived as cheap cost.

Loan maturity is also a critical aspect with Uganda exhibiting the shortest known loan maturity of twelve months in comparison to Kenya, Brazil, China and India (CGAP report, 2011). Credit policies adopted in lending to firms are seen to meet working finance requirements for SME and not for asset creating and development in the long term and 
it is limited to loans that are due in less than twelve months (Mungai and Miller, 2010).

According to Moscalu et al. (2019) and Kamunge et al. (2014), it was agreed that shorter-term credits will prevail. The implication of the short-term credit is noted when new funding is needed or being applied for. This is because the loan repayment period is expected to be shorter since the lenders fear the default probability of the SMEs involved. The conclusion was that to be loaned, the SMEs must have savings with them that will act as collateral and if possible, get more guarantors against their credit and the deposits should be held all along during the credit life, and also the interest paid on the deposits are far below the interest the SMEs pay on their loans. These deposits are meant to reduce the net cash advanced to the SMEs and the increase in the cost of credit effectively. About $33 \%$ of the reliable MFIs in 2006 needed such savings accounts, and in most cases, these MFIs are usually smaller compared to ones that lack compulsory savings (European Microfinance week, 2013)

According to World Bank (2016), corporate finance and fundamentals of lending found that lending through groups is the new institutional arrangement, however, only a few group lending schemes have been successfully done. The other attempts have had mixed performance results in various geographical areas, for example, it has worked well in Asia but poorly in Kenya since there is no indigenous organization mandated to ensure that works in Kenya. The conclusion was that the formal lenders have very rigid lending procedures and systems and very detailed and complex conditions to advance credit.

Nairobi County lenders were characterized by the high tariff charges on the facilities (Tewari et 1., 2013). Moreover, before applying for any loan, the major consideration was the interest charge. The respondents' view was that the interest rates coupled with the long-time span between application and disbursement were the major discouraging factors with the credit applications. The study postulated that accessibility, acceptability, ethical soundness are the virtues that influence credit access positively and that there is supposed to be proper strategies to guide on accessibility. Muguchu (2013) concluded that in Nairobi, access to credit amongst SMEs is marked by mostly small amounts of funds due to the assessing and loaning criteria and also because the SMEs are not willing to apply for large amounts of credit as a result of absence in willingness and effort of paying.

\section{RESEARCH METHODOLOGY}

\section{Research Design}

The study used a descriptive approach and method. This research design is applicable when a problem has undergone a well-elaborated process and analysis. The researcher chose this design since the population was clearly defined and the problem under study was well understood. The variables under the study were grouped into two: depended and the independent variables. The independent variable was lending procedures.

Lending procedures are the processes and formalities that guide granting of credit to potential borrowers. It could influence if the individuals in SME got credit or not. They vary from institution to another; however, all lenders have the procedures they adopt. It has been confirmed from various studies that these have a significant influence on whether an SME qualifies for credit from the lender with very little chance of deviation from the set policies and procedures.

The dependent variable was credit accessibility. This refers to the ease at which an SME is able to access funding by way of borrowing from financial institutions. This is a mix of a variety of elements as per the research study. The researcher considered various independent variables to be the guiding elements on what the scope of the study should be 
since this is a very wide area of study. Therefore, the four independent variables give the scope of what was studied in the research which was not fully exhausting as the possible determinants of credit accessibility amongst the SMEs

\section{Study Population and Scope}

The research study was based in Meru town. Meru County government has registered a total of 160 SME's to operate their business within the town that is regarded as aged three years in existence and above. The research data was collected only among SME owners and where they could not be traced the researcher relied on the SME's manager for information collection.

The scope encompasses the population list from which the test is done and the extent to which the study goes (Kothari, 2014). This study used all the 160 SMEs that are recognised by Meru county administration with a minimum operation period of 3 years. Due to the fact that Meru town is the biggest and oldest town, it gives it the qualification to be the leading commercial centre for entire Meru County. The registration of all SME's in the town is done in Meru town (Meru County Government, 2016). Table 1 below shows the classification and number of SMEs in Meru town.

\section{Table 1: Classification and number of SMEs in Meru town}

\begin{tabular}{ll}
\hline Strata & Total number of SMEs \\
\hline Bars, Hotels and restaurants & 11 \\
Electronics, phones and accessories shops & 17 \\
Retail and wholesale shops & 24 \\
Hardware shops & 7 \\
Barbershops and hair salon & 11 \\
Cloth boutiques and shops selling cloth products & 12 \\
Cosmetics and beauty products shops & 10 \\
Motor cars and motorbike spare parts & 6 \\
Pharmacies, clinics, chemists and health centres & 8 \\
M-Pesa and telecommunication and related products shops & 24 \\
Cyber café & 6 \\
Butcheries & 11 \\
Workshops-furniture and metal works (both timber and metal) & 7 \\
Matatu transport & 6 \\
Total & $\mathbf{1 6 0}$ \\
\hline
\end{tabular}

Source: Registrar of businesses, Meru county government

\section{Data Collection Instruments}

The collection of data was achieved through the use of questionnaires that contained a close-ended type of questions. The questionnaires contained easy to answer questions arranged in a logical manner. Convenient and straight forward guidelines were given in the questionnaire to assist the respondents in answering the queries confidently. The method was favourable since it was bias-free, which arises in interviews, there was adequate time to answer questions, reach out to respondents, and the outcome was reliable.

A Drop and Pick technique was the means for collecting information after prior booking of a special interview with the defendants. The technique helped distribute the question forms to the sample target with the assurance of accessing the respondents without any apparent force of influence. The respondents had three consecutive days to adequately fill the forms at their own 
convenient time before gathering back the filled forms.

\section{Instrument Reliability/Pilot Study}

Grady (2010) illustrates reliability as the degree level to which a study instrument produces consistent output or data following successive repetition. The test-retest method was carried out and record of the 16 question forms tabulated into version 22 of the Statistical Package for Social Sciences to adequately test and prove its reliability. Pearson interrelation coefficient was adopted to validate the efficiency of the questionnaires. The test realised a 0.772 coefficient which was analysed as a very high degree of internal consistency. The closer a coefficient is to correlation factor 1 , the better the consistency of the experiment (Kothari, 2010).

\section{Analysis and Presentation of Data}

Descriptive analysis was adopted to study the data. According to Kothari (2014), descriptive analysis is a method for assessing the correlation between the autonomous and secondary variables. Analysis of the data was conducted using the current version of SPSS, version 22, which subjects the data collected to a series of numerous regressions for test and a conclusion drawn to check whether there is any interrelation between loaning process and credit accessibility amongst SME's businesses in Meru town. The evaluated data were presented through tables. To check on the influence of the independent variable on the dependent variable, regression analysis was used.

A dependent variable represented as $\mathrm{Y}$ is equated to the summation of (Equation 1):

$$
Y=\beta_{1}+\beta_{1} X_{1}+e
$$

With the variables being defined as; $\mathrm{Y}=\mathrm{SME}$ 's credit accessibility; $\beta_{0}=$ Constant; $\beta_{1}=$ Correlation coefficient of lending procedure; $\mathrm{X}_{1}=$ Lending Procedures; $\mathrm{e}=$ Error term of the model.

\section{RESEARCH FINDINGS}

\section{Demographic Distribution of Respondents}

Out of the total 160 questionnaires, 152 were filled properly while 8 had unclear and unreliable information which were neglected and not used as part of the responses analysed. This gave a response rate of $95 \%$. Majority of the respondents were male $(105,69.1 \%)$ while $47(30.9 \%)$ were female. This implies that men form a majority of the SMEs proprietors or managers, therefore, gender has an influence on the type of business undertaken. Most of the respondents are aged between 31-35 years $(43,28 \%)$, followed by age bracket between $36-40$ years $(17,8 \%), 41-45$ age bracket $(26,17 \%), 25-30$ years age bracket $(22,15 \%)$, below 25 years $(19$, $12 \%), 46-50$ age bracket $(12,8 \%)$ and finally, over 50 years of age were $3(2 \%)$ participants. The results showed that majority of the business proprietors and managers in the SMEs are middleaged showing age also has an influence on the SMEs business and the existence levels.

Most of the respondents had secondary education forming (79) $52 \%$, those who have diploma education level form (29) 19\%, 22 (14\%) respondents had primary education level while those with a degree and post-degree were 18 (12\%) and $4(3 \%)$ respectively. This shows that people with secondary education are the main group who are interested in SMEs business. According to the findings, $50 \%$ (76) of the SMEs have been in operation for a period between 3-5 years, 35\% (53) for $5-10$ years, $7 \%$ (11) for 11-15 years, 3\% (5) for $16-20$ years and $5 \%$ (7) above 21 years. This shows the majority of the businesses forming the research population have been in operation for 3-5 years.

\section{Descriptive Findings}

In addition, the respondents had to give their opinions regarding the lending procedures and its effect on their credit access amongst the SMEs in Meru town. The responses were ranked on scales of five points were $1,2,3,4$, and 5 represented strongly 
disagree, disagree, neutral, agree and strongly agree respectively. The respondents were asked to give their rating on the satisfaction level with lending procedures.

According to the findings, the respondents agreed that the loans application and evaluation process was difficult $(M=4.12, S D=0.767)$. They also disagreed that the loan repayment period was favourable to them $(M=1.88, S D=-0.422)$. Moreover, they disagreed that there are few regulations when accessing credit for business $(M$ $=2.42 ; \mathrm{SD}=-1.34)$. They disagreed that there is little client evaluation that makes it easy to acquire credit $(M=1.22, S D=-0.794)$. Also, they also disagreed that the lenders do not necessarily make business premise check by visiting in order to access credit $(M=2.46, S D=-1.253)$ (Table 2).

Table 2: Descriptive statistics for lending procedures

\begin{tabular}{llllll}
\hline Lending procedures & $\mathbf{N}$ & Min & Max & Mean & Std. Dev \\
\hline Loan application process was not easy & 152 & 1 & 5 & 4.12 & 0.767 \\
\hline The loan repayment period was favourable to me & 152 & 1 & 5 & 1.88 & -0.422 \\
\hline $\begin{array}{l}\text { There are few regulations when accessing business } \\
\text { credit }\end{array}$ & 152 & 1 & 5 & 2.42 & -1.34 \\
\hline $\begin{array}{l}\text { There is little client evaluation making it easy to acquire } \\
\text { credit }\end{array}$ & 152 & 1 & 5 & 1.22 & -0.794 \\
\hline $\begin{array}{l}\text { The lending firms do not necessarily make a physical } \\
\text { business visit at the Premises in order to grant credit }\end{array}$ & 152 & 1 & 5 & 2.56 & -1.253 \\
\hline
\end{tabular}

The respondents also were requested to rate the satisfaction levels with the lending procedures in relation to credit accessibility and the following were the results. On satisfaction levels with the lending procedures, the majority are dissatisfied (53\%) (Table 3). The findings show that generally, the lending procedures do not favour the credit accessibility by the SMEs in Meru town.

Table 3: Satisfaction level with lending procedures

\begin{tabular}{lll}
\hline Satisfaction level & Frequency & Percentage \\
\hline Highly satisfied & 11 & $7 \%$ \\
Satisfied & 21 & $14 \%$ \\
Neutral & 40 & $26 \%$ \\
Dissatisfied & 74 & $49 \%$ \\
\hline
\end{tabular}

\begin{tabular}{lll}
\hline Satisfaction level & Frequency & Percentage \\
\hline Highly dissatisfied & 6 & $4 \%$ \\
Total & $\mathbf{1 5 2}$ & $\mathbf{1 0 0 \%}$ \\
\hline
\end{tabular}

Findings in Table 4 indicates that $40 \%$ of the application declines were due to the business inability to raise enough funds from their cash flows to pay off the instalments when they fall due, while $32 \%$ of the declines were due to lack of sufficient or enforceable collateral where the documents for the owners are not legally owned/enforceable. Further, $9 \%$ of the declines were due to failure to comply with regulations such as failure to renew operations license on time and finally $19 \%$ declines were not clearly indicated.

Table 4: Loan applications decline reasons

\begin{tabular}{lll}
\hline Reject reason & Frequency & Percentage \\
\hline Cash flows not able to support the loan repayment & 23 & $40 \%$ \\
No sufficient/enforceable collateral & 18 & $32 \%$ \\
Not compliant to regulations & 5 & $9 \%$ \\
No clear information given & 11 & $19 \%$ \\
Total & $\mathbf{5 7}$ & $\mathbf{1 0 0 \%}$ \\
\hline
\end{tabular}




\section{Inferential Findings}

In this section, the relationship between the dependent and the independent variables is put into an explanation. Moreover, the influence of the independent variables on the dependent variables is explained. Therefore, this outlines the results of both the correlation analysis (to explain the relationship) a regression analysis (to explain the influence of the loaning procedure on the credit accessibility).
The study examined the relationship between lending procedures and credit accessibility by SMEs in Meru town. The below table shows the correlation analysis results. From the computations, the relationship between lending procedures and credit accessibility by SMEs in Meru town is negative, strong and significant $(r=-0.894, p<$ 0.01 ) (Table 5). These results indicate that as lending procedures increase, credit accessibility reduces and vice versa. As such, to increase credit accessibility, the lending procedures should be reduced and made easier to understand to the SMEs owners and managers.

Table 5: Correlation between Dependent Variables and Credit Accessibility by SMEs

\begin{tabular}{lll}
\hline & & Credit accessibility \\
\hline Lending procedures & Pearson correlation & -0.894 \\
& Sig. (2-tailed) & 0.004 \\
& $\mathrm{~N}$ & 152 \\
\hline
\end{tabular}

Influence of Independent Variables on the the SMEs in Meru town. This was achieved through Dependent Variable regression analysis and Table 6 shows the summary

This analysis sought to explain the effect of the of the results achieved from the analysis. lending procedures on credit accessibility amongst

Table 6: Regression analysis summary

\begin{tabular}{lllll}
\hline Variable & $\boldsymbol{R}$ & $\mathbf{R}^{\mathbf{2}}$ & Adjusted R $^{\mathbf{2}}$ & Std. Dev. \\
\hline Lending procedures & -0.894 & 0.799 & 0.716 & 0.5055 \\
\hline
\end{tabular}

The predicting factor in place was lending procedures. The relationship between the lending procedures under investigation and credit accessibility is negative and strong. The $\mathrm{R}$ squared forms the part of the variance in the dependent variable that can be explained by the independent variables. In this case, that part is 0.799 meaning that the loaning procedures only account for $79.9 \%$ of credit accessibility by SMEs in Meru town.

Table 7: Regression coefficients

\begin{tabular}{|c|c|c|c|c|c|}
\hline \multirow[t]{2}{*}{ Model } & \multicolumn{2}{|c|}{ Unstandardised Coefficients } & \multirow{2}{*}{$\begin{array}{l}\text { Standardised } \\
\text { Coefficients } \\
\text { beta } \\
\end{array}$} & \multirow[t]{2}{*}{$\mathbf{t}$} & \multirow[t]{2}{*}{ Sig. } \\
\hline & B & Std Error & & & \\
\hline 1 (constant) & 1.207 & 0.443 & & 2.724 & 0.000 \\
\hline Lending procedures & -0.070 & 0.176 & -0.083 & -0.472 & 0.000 \\
\hline
\end{tabular}


Table 7 shows the overall significance test results for the hypothesis research model. The interpretations emanate from the below regression model (Equation 1).

$$
Y=\beta_{1}+\beta_{1} X_{1}+e
$$

From the model,

$Y=1.207+-0.0703 X_{1}+e$

The findings indicate that to enhance credit accessibility by 1 more unit, the lending procedures, are supposed to be reduced by 0.083 units. This was supposed to have held 1.207 constant. Lending procedures had significance level of $(t=-0.472, p<0.05)$

\section{DISCUSSION OF FINDINGS}

\section{Lending Procedures and Credit Accessibility}

From the findings, it is deduced that the loan application process is not easy and as such, the financial institutions need to make it easier for the SMEs to apply for credit. This is in agreement to Ong'olo and Awino (2013) that strict conditions meted on the SMEs to meet before they can access credit, it also agreed with the study by Nuno and Andoh (2011) that concluded that there is need to relax some procedures to make it easier for the SMEs to access credit. Moreover, the respondents disagreed that the loan repayment period was favourable; the regulations are few; client evaluation is less and that the financial institutions do not visit the SMEs business premises. This indicates that the loan repayment period should be adjusted to favour them, the stringent regulations eased and reduced the client evaluation and the customer visit process and activities. This is in line with the IFC (2010) recommendation that procedures in place should be flexible and consider the application on a case-by-case basis since no general procedure favours all the credit applications.

\section{CONCLUSIONS AND RECOMMENDATIONS}

The study concluded that the lending procedures on credit are so many and hinder the credit accessibility and are affected by the unfriendly loan application process, unfavourable loan repayment period, the numerous numbers of regulations that an SME should satisfy, the rigorous client evaluation process and the various visits the customer is subjected to before credit can be offered. It was also concluded that the government should do more in relation to regulation easing and enhance credit accessibility. This can be done through prioritising shaping of credit access programs and ensure that even the SME sector is considered in policy framing.

The study sought to establish the determinants of credit accessibility amongst the SMEs in Kenya; a case of Meru town and the recommendations as arose from the study. The lenders are required to relax lending procedures to be more flexible to accommodate the SME sector to enable them access credit; this will be effectively done by easing loan application process and subjecting them to fewer evaluation steps. Since there seems to be information incongruence in regards to what credit facilities are available and where they can be accessed, the entrepreneurs are required to engage deeply with the various organisations such as government bureaus, the lenders in the network by physical visits and engaging in societal groups and study the information sources deeply to have a clear glimpse of what the environment has to offer in terms of credit assistance. They are also expected to ensure proper record keeping and management to ensure systems are in place for ease of access to business information for ease of evaluation of credit by the lenders when applications are made.

\section{Suggestions for Further Studies}

The study suggests that the same study should be carried out in other areas in Kenya to establish 
whether the same findings and conclusions will be found to be true and replicated in other places. It also suggests that further studies should be carried out to get the other factors that determine credit accessibility since it has been established that the variables as the study investigated can only affect $64.4 \%$ on credit accessibility.

\section{REFERENCES}

Andoh, F. K. \& Nunoo, J. (2011). Sustaining small and medium enterprises through financial service utilisation: does financial literacy matter? Agricultural \& Applied Economics Association's 2012 AAEA Annual Meeting, Seattle, Washington.

Bergthaler, W., Kang, K., Liu, Y., \& Monaghan, D. (2015). Tackling Small and Medium Sized Enterprise Problem Loans in Europe. IMF Staff Discussion Note SDN/15/04. International Monetary Fund.

CBK. (2015). Bank Financing of SMEs in Kenya. Retrieved from https://www.centralbank.go.ke/images/docs/Ba nk\%20Supervision\%20Reports/BankFinancing SMEsKenya.pdf

Central Bureau of Statistics. (2018). A study on SME financing challenges relating to access to finance and their general financial needs. Retrieve from http://viffaconsult.co.ke/wpcontent/uploads/2018/07/2018-SME-FinanceSurvey-Report.pdf

ECD. (2019). Financing SMEs and Entrepreneurs. An OECD scoreboard. Paris, France: OECD Publishing. DOI: 10.1787/fin_sme_ent-2019-en

Edinburgh Group. (2013). Growing the Global Economy through SMEs. Edinburgh Group

European Commission (2016). Entrepreneurship and Small and Medium-sized Enterprises (SMEs). Retrieved from http://ec.europa.eu/growth/smes/
Grady, M. P. (2010). Qualitative and Action Research: A Practitioner Handbook. Bloomington, Indiana USA: Phi Delta Kappa Educational Foundation.

IFC. (2016). SME Initiatives. Retrieved from International Finance Corporation, http://www.ifc.org/wps/wcm/connect/region_ ext_content/regions/subsaharan+africa/advisory+services/sustainablebu siness/sme_initiatives/sme_initiatives

Kamunge, M. S., Njeru, A. \& Tirimba, O. I. (2014). Factors affecting the performance of small and macro enterprises in Limuru town market of Kiambu County. International Journal of Scientific and Research Publications, 4(12),120.

Kothari, C. R. (2014). Research Methodology: Methods and Techniques ( $3^{\text {rd }}$ Ed.). New Delhi: New Age (P) Limited International Publisher.

Miller, M., \& Mungai, G. (2015). Pricing and costing SME products and service. Project Technical Note. Nairobi, KE: FSD Kenya

Moscalu, M., Girardone, C., \& Calabrese, R. (2020). SMEs' growth under financing constraints and banking markets integration in the euro area. Journal of Small Business Management, 58(4), 707-746.

Muguchu, M. (2013). The relationship between access to credit and financial performance of small and medium enterprises in Nairobi, Kenya. Unpublished thesis. University of Nairobi.

Njiru, B. N. (2014). The effect of cost of credit on the financial Performance of commercial dairy small and medium Enterprises in Kiambu county. Doctoral dissertation. University of Nairobi.

Ong'olo, D., \& Awino, S. (2013). Small and medium enterprises and devolved government 
system: An assessment of the regulatory and institutional challenges affecting the SMEs Development in Kenya. ICBE-RF Research Report N0. 71/13. Dakar: Investment Climate and Business Environment Research Fund (ICBE-RF)

OECD (2015). Enhancing the contributions of SMEs in a global and digitalised economy. Better policies for better lives. Paris: OECD Publishing.

Öztürk, B., \& Mrkaic, M. M. (2014). SMEs' access to finance in the euro area: what helps or hampers? (Working Paper No. 14-78). International Monetary Fund.

Sultana, A. (2012). Promoting women's entrepreneurship through SME: Growth and development in the context of Bangladesh. IOSR Journal of Business and Management, 4(1), 18-29.

Tewari, P. S., Skilling, D., Kumar, P., \& Wu, Z. (2013). Competitive small and medium enterprises: A diagnostic to help design smart SME policy. World bank group.

World Bank. (2015). Small and Medium Enterprises (SMEs) Finance. Retrieved from http://www.worldbank.org/en/topic/financialse ctor/brief/smes-finance.

World Bank. (2016). Kenya Economic Memorandum. From economic Growth to Jobs and Shared Prosperity. Nairobi, KE: World Bank. 